\title{
'Tahiti' lime fruit set related to gibberellic acid application on out-of-season flowering and the accumulation of degree days
}

Marcel Bellato Spósito ${ }^{a}$ Francisco de Assis Alves Mourão Filhob*

a Fundecitrus, CP 391, Araraquara, SP, 14801-970, Brazil

marcel@fundecitrus.com.br

b Departamento de Produção Vegetal, USP/ESALQ, CP 9, Piracicaba, SP, 13418-900, Brazil

famourao@esalq.usp.br
* Correspondence and reprints

Received 23 August 2002 Accepted 7 January 2003

Fruits, 2003, vol. 58, p. 151-156 (C) 2003 Cirad/EDP Sciences All rights reserved

DOI: $10.1051 /$ fruits:2003003

RESUMEN ESPAÑOL, p. 156
'Tahiti' lime fruit set related to gibberellic acid application on out-of-season flowering and the accumulation of degree days.

Abstract - Introduction. The production of 'Tahiti' limes in southern Brazil has increased in the last 20 years and has become a good alternative for citrus growers in regions where Citrus Variegated Chlorosis has affected sweet orange groves. One of the main goals to insure success in growing 'Tahiti' limes is to apply the right techniques to induce out-of-season flowering and winter fruit harvest when the fruit prices are the highest. This experiment evaluated the effects of gibberellic acid application on fruit set of 'Tahiti' lime trees related to out-of-season flowering and accumulated degree days. Materials and methods. Eight-year-old plants were treated with five concentrations of gibberellic acid $\left[\left(0,10,25,50\right.\right.$ and 100) $\left.\mathrm{mg} \cdot \mathrm{L}^{-1}\right]$ applied during anthesis of out-of-season bloom. Accumulation of degree days for fruit set and fruit development in the conditions of São Paulo State, Brazil, were calculated. The percentage of fruit set determined by weekly counts of the number of flowers from anthesis to the maturation of the fruits were determined on each previously marked branch. Data were submitted to regression analysis. Results and discussion. In regard to fruit set, it was observed that $10 \mathrm{mg}$ gibberellic acid $\cdot \mathrm{L}^{-1}$ was enough to retain more than $10 \%$ of fruits in relation to the number of formed flowers. Starting from anthesis, (837.7 and 1115.2) accumulated degree days were necessary for the stabilization of the fruit set and fruit maturation, respectively.

Brazil / Citrus latifolia / flowering / fruiting / plant developmental stages / maturation / plant growth substances

Influence de l'acide gibbérellique et de l'accumulation des températures journalières sur la nouaison de la lime 'Tahiti'.

Résumé - Introduction. La production de lime 'Tahiti' au sud du Brésil a augmenté ces vingt dernières années, offrant un nouveau créneau pour les producteurs dans les régions où la "chlorose variégée des agrumes", ou CVC, affecte les plantations d'oranges douces. L'un des principaux facteurs permettant de garantir le succès croissant du limettier 'Tahiti' est l'application de techniques adéquates pour induire une floraison hors-saison et une récolte au cours du second semestre, au moment où les prix sont les plus hauts. Notre expérimentation a évalué la nouaison du limettier 'Tahiti' en fonction de l'application d'acide gibbérellique et de la somme des températures journalières. Matériel et méthodes. Des plants âgés de 8 ans ont été traités avec cinq concentrations d'acide gibbérellique $\left[(0,10,25,50,100) \mathrm{mg} \cdot \mathrm{L}^{-1}\right]$ appliquées durant le développement du fruit. Les sommes de températures diurnes ont été calculées dans les conditions de l'État de São Paulo, Brésil, vis-à-vis de la nouaison et du développement des fruits. Le pourcentage de fruits noués mesurés à partir de comptages hebdomadaires du nombre de fleurs de l'anthèse jusqu'à la maturation du fruit a été calculé pour chacune des branches préalablement marquées. Ces données ont été soumises à une analyse de régression. Résultats et discussion. Une concentration de $10 \mathrm{mg} \cdot \mathrm{L}^{-1}$ d'acide gibbérellique a été suffisante pour fixer plus de $10 \%$ des fruits formés à partir des fleurs comptabilisées. À partir de l'anthèse, pour la stabilisation de la nouaison et de la maturation, il a fallu respectivement une somme de $(837,7$ et 1115,2$)$ degrés de températures journalières.

Brésil / Citrus latifolia / floraison / fructification / stade de développement végétal / maturation / substance de croissance végétale 


\section{Introduction}

Flower and fruit abscission after full blooming is mainly a result of competition for carbohydrates, water, and other metabolites and is considered to be regulated by an internal hormonal balance [1]. The number of harvested fruits normally do not exceed $10 \%$ of formed flowers, occasionally reaching values between $(0.1$ and 3.5$) \%[2,3]$.

In seedy varieties, fruit set depends on increased levels of endogenous hormones synthesized in the seeds, especially gibberellins, that increase the demand for photosynthetic products and minerals and, therefore, reduce the abscission of ovaries and young fruits $[4,5]$. In parthenocarpic varieties, fruit set is probably influenced by the ovary walls where the synthesis of the receptors that regulate fruit set normally occurs [6]. Fruit set can be easily achieved in seedy varieties, sometimes beyond the desirable rate and thereby resulting in alternate bearing [7].

Exogenous application of gibberellic acid is efficient in raising the fruit set rate, primarily in mandarins and mandarin hybrids [8, 9]. However, responses to exogenous application of this growth regulator is observed only when that application is done at the stage of maximum sensitivity, e.g., when the endogenous levels of this hormone are lower than those necessary to elicit a response [8]. Previous research has shown that maximum fruit set occurs when gibberellic acid is applied between anthesis and petal fall $[9,10]$.

Temperature is the most important environmental factor affecting plant development [11]. The most widely used temperature model for predicting phenological development is based on accumulated degree days [12]. Degree days are the number of degrees by which the daily average temperature differs from a defined base temperature. This can be useful for improving agricultural management practices and harvesting schedules, selecting suitable crops for planting in a given area, and organizing models for forecasting the commencement and duration of phenological periods [13-15]. The relationship of degree day accumulation corresponding to citrus fruit development has been studied by several authors [13-18]. However, there have been few studies about fruit set and fruit maturation of 'Tahiti' limes [19, 20].

The production of 'Tahiti' limes in southern Brazil has increased in the last 20 years and has become a good alternative for citrus growers in regions where the "Citrus Variegated Chlorosis" has affected sweet orange groves. In that country, 'Tahiti' lime produces many blooms throughout the year and is dependent upon environmental conditions. The most important bloom occurs in spring (September/October) and results in a harvest of fruits during the summer (February/March). Another important bloom, but much smaller than the spring bloom, occurs in summer (February/March) and results in a harvest of fruits during the winter (August/September). The highest prices of 'Tahiti' limes are observed during the second bloom of the year, when the amount of fruit harvested is less [21].

This research evaluated the fruit set of 'Tahiti' limes and calculated the amount of degree days necessary from flower to fruit set stabilization and fruit maturation in response to application of gibberellic acid during out-of-season flowering.

\section{Materials and methods}

The experiment was carried out at the Universidade de São Paulo, Piracicaba, São Paulo State, Brazil. The geographical location is $22^{\circ} 43^{\prime \prime}$ south latitude, $47^{\circ} 38^{\prime \prime}$ west longitude, $576 \mathrm{~m}$ above sea level. The climate is Cwa, i.e., humid tropical, with a dry winter and rainy summer [22], with an average temperature of $21.1{ }^{\circ} \mathrm{C}$, annual rain fall of $1253 \mathrm{~mm}$, relative humidity of $74 \%$ and average monthly solar radiation of $201.5 \mathrm{~h}$.

The experimental plantings consisted of 8-year-old 'Tahiti' lime trees (Citrus latifolia Tanaka) budded on 'Rangpur' lime (Citrus limonia L. Osbeck), planted at $(8.0 \times$ 5.0) $\mathrm{m}$, and irrigated with microsprinklers. At the experimental site, the soil is classified as a Kandiudalfic Eutrudox [23].

The trial started in the second half of March 1998 with the selection of four 
out-of-season flowering branches in each experimental plant. Treatments were directly applied to each flowering branch by localized spraying of $0.5 \mathrm{~L}$ of gibberellic acid solution. Treatments applied were: control $\left(0 \mathrm{mg} \cdot \mathrm{L}^{-1}\right)$ and $(10,25,50$ and 100) $\mathrm{mg} \cdot \mathrm{L}^{-1}$ of gibberellic acid $\left(\mathrm{GA}_{3}\right)$. The experimental design was completely randomized blocks with four replications and two plants per plot, yielding a total of 40 plants.

The percentage of fruit set in each treatment was determined by weekly counts of the number of flowers and fruits from anthesis to fruit maturation on each previously marked branch. Fruits were considered fully matured when the Brix/acid ratio was above 1.5 and the minimum diameter was $40 \mathrm{~mm}$ [24].

The number of days and weekly degree day accumulation were summed from anthesis to fruit set stabilization and to fruit maturation. These summations were obtained for in-season flowering (from October, 1997 to February, 1998) and outof-season flowering (from March, 1998 to August, 1998) by the formula described below [15]:

$$
\mathrm{DD}=\sum_{\mathrm{i}=1}^{\mathrm{n}}(\mathrm{Ti}-\mathrm{Tb})
$$

where: DD: degree days; $\mathrm{Ti}=\left(\mathrm{T}_{\max }+\right.$ $\mathrm{T}_{\min }$ ) / 2, with $\mathrm{T}_{\max }$ : maximum temperature and $\mathrm{T}_{\text {min }}$ : minimum temperature; $\mathrm{Tb}$ : basal temperature $\left(13^{\circ} \mathrm{C}\right.$, for citrus).

The fruit set percentage data for different gibberellic acid concentrations were submitted to analysis of variance and compared by regression analysis. Degree day accumulations were submitted to analysis of variance and the average fruit set and accumulated degree days were compared by regression analysis.

\section{Results and discussion}

\subsection{Fruit set related to gibberellic acid application}

The application of gibberellic acid in 'Tahiti' lime to increase fruit set has never

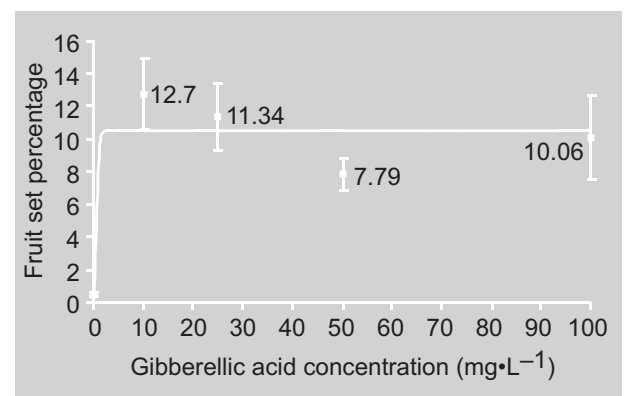

been reported, probably because this citrus species produces relatively high yields. However, in Brazil, the maturation period occurs mostly during the first months of the year. During the second semester, the production is normally low and therefore the fruit commands a high price [21]. Applying gibberellic acid to out-of-season flowers showed an increase in fruit set when compared with the control (figure 1).

The percentage of out-of-season fruit set in the control $\left(0 \mathrm{mg} \cdot \mathrm{L}^{-1} \mathrm{GA}_{3}\right)$ was 0.46 . In another experiment, the percentage of fruit set was 1.85 for the main bloom in September [19]. This difference occurred probably due to the amount of carbohydrate reserves in the plants, much higher in spring following a dormant winter period, than in the summer period. However, when out-ofseason flowers received $10 \mathrm{mg} \cdot \mathrm{L}^{-1} \mathrm{GA}_{3}$, the percentage of fruit set was 12.75 . This increase was probably related to the sink power of exogenous gibberellic acid applied to the 'Tahiti' lime flowering branches [4]. The variance analysis and F test showed that the difference of average fruit set of out-of-season 'Tahiti' limes for different concentrations of gibberellic acid was significant.

The Mitscherlich-Bray's exponential model was the one that best related the average fruit set of out-of-season 'Tahiti' limes with different concentrations of gibberellic acid. The equation of MitscherlichBray's exponential model is represented by the formula below: $y=\mathrm{A}\left[1-10^{-\mathrm{c}(x+\mathrm{b})}\right]$, where $y=$ fruit set (\%), $\mathrm{A}=$ maximum theoretical fruit set $(\%)$; $\mathrm{c}=$ efficiency coefficient; $\mathrm{b}=$ estimated endogenous gibberellic acid concentration $\left(\mathrm{mg} \cdot \mathrm{L}^{-1}\right) ; x=$ exogenous gibberellic acid concentration $\left(\mathrm{mg} \cdot \mathrm{L}^{-1}\right)$.
Figure 1.

Fruit set percentage of 'Tahiti' lime and standard error in different concentrations of gibberellic acid applied during the anthesis period of out-ofseason flowering, evaluated during harvest (Piracicaba-SP, Brazil, 1998). 


\begin{tabular}{|c|c|c|c|c|}
\hline \multirow[t]{2}{*}{ Year } & \multicolumn{2}{|c|}{ From anthesis to fruit set } & \multicolumn{2}{|c|}{ From anthesis to harvest } \\
\hline & Calendar days & Degree days & Calendar days & Degree days \\
\hline In-season ${ }^{1}$ & 773 & 967 & 106 & 1338 \\
\hline Out-of-season ${ }^{2}$ & 126 & 837 & 162 & 1115 \\
\hline Mean & 101.5 & 902 & 134 & 1226.5 \\
\hline CV & 34.1 & 10.2 & 29.5 & 12.8 \\
\hline
\end{tabular}

According to the equation, the concentration of $10 \mathrm{mg} \cdot \mathrm{L}^{-1} \mathrm{GA}_{3}$ was enough to increase fruit set in 'Tahiti' lime (figure 1). This concentration has been recommended to citrus growers in South Africa and Spain for 'Clementine' mandarin $[8,25]$. However, the equation curve shows that the concentration of $3 \mathrm{mg} \cdot \mathrm{L}^{-1} \mathrm{GA}_{3}$ could induce maximum fruit set. This concentration is very similar to that recommended for "Clemenules' mandarin in Spain $\left(2.5 \mathrm{mg} \cdot \mathrm{L}^{-1} \mathrm{GA}_{3}\right)$, to ensure fruit set in out-of-season flowering [8].

\subsection{Degree days accumulation}

Knowing when to expect fruit set is very important to estimate the harvest period better. It is also important to the citrus grower to know the necessary period between flowering and fruit maturation. The goal is to induce flowering at an appropriate time to ensure the maximum harvest at the time of the year when the prices are higher. Some research suggests that the period between flowering and fruit maturation in 'Tahiti' lime is 120 calendar days [26]. However, fruit growth is related, among other factors, to environmental conditions, especially temperature [27]. Therefore, the specification of a certain period of calendar days may lead to mistakes in predicting harvest time, especially when comparing distinct production regions with different average temperatures. That is a primary reason that the degree-days method for the estimation of fruit maturation has been studied for several crops [15]. 'Tahiti' lime matures after 1220 degreedays [20].

In this experiment, for in-season flowering (October, 1997), an accumulation of 967 degree days in a period of 77 calendar days was necessary during anthesis to fruit set stabilization and 1338 degree days in 106 calendar days were necessary for fruit maturation. For out-of-season flowering (March, 1998), an accumulation of 837 degree days in 126 calendar days was necessary during anthesis to fruit set stabilization and 1115 degree days in 162 calendar days were necessary for fruit maturation (table I).

The periods from anthesis to fruit set stabilization and from anthesis to harvest were compared for in-season flowering and out-of-season flowering by calendar day and degree day accumulation (table I). The coefficients of variation were low for degree days accumulated in fruit set stabilization and fruit maturation for both flowerings when compared with calendar days accumulated. These results showed that degree day accumulation was more accurate than calendar day accumulation to predict fruit set stabilization and maturation.

The results obtained herein can be a useful guide for having adequate fruit set on out-of-season flowering in 'Tahiti' lime and thereby increase the yield and income of lime harvest in the second semester in 
Brazil. Using the accumulated degree days to estimate fruit maturation, it is possible to know when to induce flowering and, therefore, harvest fruit during more profitable periods.

\section{Conclusion}

Exogenous gibberellic acid applied during petal fall to the out-of-season 'Tahiti' lime flowers increases the fruit set. The utilization of $10 \mathrm{mg} \cdot \mathrm{L}^{-1} \mathrm{GA}_{3}$ was enough to set more than $10 \%$ of possible fruits. The accumulation of degree days showed less variation when compared with the accumulation of calendar days for the period from anthesis to harvest.

\section{References}

[1] Powell A.A., Krezdorn A.H., Influence of fruitsetting treatment on translocation of $14 \mathrm{C}$ metabolites in citrus during flowering, J. Am. Soc. Hortic. Sci. 102 (1977) 709-714.

[2] Agustí M., García-Marí F., Guardiola J.L., The influence of flower intensity on the shedding of reproductive structures in sweet orange, Scientia Hortic. 17 (1982) 343-352.

[3] Monselise S.P., Citrus, in: Monselise S.P. (Ed.), Handbook of fruit set and development, CRC Press, Boca Raton, USA, 1986, pp. 87-108.

[4] Talon M., Tadeo F.R., Bem-Cheikh W., Gomez-Cadenas A., Mehouachi J., PérezBotella J., Primo-Millo E., Hormonal regulation of fruit set and abscission in citrus: classical concepts and new evidence, Acta Hortic. 463 (1997) 209-217.

[5] Bem-Cheikh W., Pérez-Botella J., Tadeo F.R., Talón M., Primo-Millo E., Pollination increases gibberellin levels in developing ovaries of seeded varieties of citrus, Plant Physiol. 114 (1997) 557-564.

[6] Monselise S.P., Citrus fruit development: endogenous systems and external regulation, in: ISC, Proc. Int. Soc. Citric., vol. 2, Int. Soc. Citric., Orlando, USA, 1977, pp. 664668.

[7] Spósito M.B., Castro P.R.C., Agustí M., Alternância de produção em citros, Laranja (Cordeirópolis, Brazil) 19 (1998) 293-304.
[8] Agustí M., Almela V., Aplicación of fitorreguladores en citricultura, Aedos, Barcelona, Spain, 1991, 261 p.

[9] Castro P.C.R., Reguladores vegetais na citricultura tropical, in: Donadio L.C., Rodriguez O., Semin. int. citros, 5, Fundação Cargill, Campinas, Brazil, 1998, pp. 463-479.

[10] García-Martínez J.L., García-Papí M.A., The influence of gibberellic acid, 2,4-diclorophenoxyacetic acid and 6-benzylaminopurine on fruit-set of clementine mandarin, Scientia Hortic. 10 (1979) 285-293.

[11] Bustan A., Erner Y., Goldschmidt E.E., Integrating temperature effects on fruit growth in a Citrus productivity model, in: ISC, Proc. Int. Soc. Citric., vol. 2, Int. Soc. Citric., Sun City, South Africa, 1996, pp. 938-944.

[12] Slafer G.A., Savin R., Development base temperature in different phenological phases of wheat (Triticum aestivum) J. Exp. Bot. 43 (1991) 1077-1082.

[13] Bem Mechiliia N., Carrol J.J., Agroclimatic modeling for the simulation of phenology, yield and quality of crop production. I - Citrus response formulation, Int. J. Biometeorol. 33 (1989) 36-51.

[14] Kimball D.A., Factors affecting the rate of maturation of citrus fruits, in: Timmer L.W., Proc. Fla. State for Hortic. Soc., Fla. State. Hortic. Soc., Miami, USA, 97, 1984, pp. 40-44.

[15] Volpe, C. A., Fenologia dos citros, in: Donadio L.C., Sem. Int. citros, 2, Fundação Cargill, Campinas, Brazil, 2, 1992, pp. 107120.

[16] Ortolani A.A., Pedro J.R., Alfonsi R.R., Agroclimatologia e o cultivo dos citros, in: Rodriguez O., Viégas F., Pompeu Jr. J., Amaro A. (Eds), Citricultura brasileira, Fundação Cargill, Campinas, Brazil, 1, 1991, pp. 153-188.

[17] Stanhill G., Quantifying weather-crop relation, in: Landsberg J.J., Environmental effects on crop physiology, Acad. Press, London, UK, 1977, pp. 23-37.

[18] Reuther W., Climate and citrus behavior, in: Reuther W., Batchelor L.D., Webber H.J. (Eds.), The citrus industry, Univ. Calif. Press, vol. 3, Riverside, USA, 1973, pp. 280-337.

[19] Spósito M.B., Mourão Filho F.A.A., Araújo P.S.R., Fixação e maturação de frutos de limeira ácida 'Tahiti' em relação aos quadrantes geográficos da copa e ao 
acúmulo de graus-dias, Rev. Brasil. Frutic. 22 (2000) 124-127.

[20] Sentelhas P.C., Coelho Filho M.A., Pereira A.R., Estimativa da época adequada para o florescimento da lima ácida 'Tahiti', visando à produção na entressafra no Estado de São Paulo, Laranja (Cordeirópolis, Brazil) 20 (1999) 135-151.

[21] Anonymous, Agrianual 2001: anuário da agricultura brasileira, FNP Consultoria \& Comércio, São Paulo, Brazil, 2001, 545 p.

[22] Köppen W., Climatologia: com un estudio de los climas da tierra, Fondo de cultura económica, Mexico, 1948, 478 p.

[23] Vidal-Torrado P., Sparovek G., Mapa pedológico detalhado do campus "Luiz de
Queiroz" (escala 1:10,000), ESALQ, Piracicaba, Brazil, 1993.

[24] Figueiredo J.O., Variedades copa de valor comercial, in: Rodriguez O., Viégas F., Pompeu Jr. J., Amaro A. (Eds), Citricultura brasileira, 1, Fund. Cargill, Campinas, Brazil, 1991, pp. 228-264.

[25] Lange J.H., Plessis S.F., Vicent P., Preez M.B., Holmden E.A.; Rabe E., Studies on Clementine yield, fruit size and mineral composition of leaves, Subtropica 3 (1982) p. 7.

[26] Marcondes P.T.S., Coelho Y.S., Crescimento do fruto de limão 'Tahiti' (Citrus latifolia Tanaka), Rev. Brasil. Frutic. 13 (2) (1991) 203207.

[27] Agusti M., Citricultura, Mundi-Prensa, Madrid, Spain, 2000, 416 p.

\section{Influencia del ácido giberélico y de la acumulación de temperaturas diarias en la fructificación de la lima 'Tahití'.}

Resumen - Introducción. La producción de lima 'Tahití' en el sur de Brasil se ha incrementado en los últimos veinte años, proporcionando una nueva salida a los productores en las regiones en las que la "clorosis variegada de los cítricos", o CVC, afecta las plantaciones de naranja dulce. Uno de los principales factores que permiten garantizar el creciente éxito del limero 'Tahití' es la aplicación de técnicas adecuadas para inducir una floración fuera de temporada y una cosecha durante el segundo semestre, cuando los precios son más altos. En nuestro experimento se evaluó la fructificación del limero 'Tahití' en función de la aplicación del ácido giberélico y de la suma de temperaturas diarias. Material y métodos. Plantas de 8 años fueron tratadas con cinco concentraciones de ácido giberélico $[(0,10,25,50$, 100) $\mathrm{mg} \cdot \mathrm{L}^{-1}$ ] aplicadas durante el desarrollo del fruto. Las sumas de temperaturas diurnas se calcularon en las condiciones del Estado de São Paulo, Brasil, en función de la fructificación y del desarrollo de los frutos. En cada una de las ramas previamente marcadas, se calculó el porcentaje de frutos cuajados evaluado a partir de recuentos semanales del número de flores desde la antesis hasta la maduración del fruto. Estos datos se sometieron a un análisis de regresión. Resultados y discusión. Una concentración de $10 \mathrm{mg} \cdot \mathrm{L}^{-1}$ de ácido giberélico fue suficiente para fijar más del $10 \%$ de los frutos formados a partir de las flores contabilizadas. A partir de la antesis, para la estabilización de la fructificación y de la maduración, se necesitó respectivamente una suma de 837,7 y 1115,2 grados de temperaturas diarias.

Brasil / Citrus latifolia / floración / fructificación / etapas de desarrollo de la planta / maduración / sustancias de crecimiento vegetal

To access this journal online: www.edpsciences.org 